\title{
ECOLOGICAL ASSESSMENT OF THE STATE OF ROCKS IN THE OF RECLAMATION PROCESS IN THE NIKOPOL MANGANESE ORE BASIN
}

\author{
Kharytonov M.M. \\ Dnipro State Agrarian and Economy University \\ (DSAEU), Professor, Doctor of Agricultural Sciences, Professor, De- \\ partment of Soil Sciences and Farming, Ukraine \\ Gonchar N.V. \\ Dnipro State Agrarian and Economy University \\ (DSAEU), Associate Professor, Candidate of Agricultural Sciences, \\ Professor, Department of Soil Sciences and Farming, Ukraine \\ Gavryushenko O.O. \\ Dnipro State Agrarian and Economy University \\ (DSAEU), Associate Professor, Candidate of Agricultural Sciences, \\ Professor, Department of Soil Sciences and Farming, Ukraine

\section{Mytsyk O.O.} \\ Dnipro State Agrarian and Economy University
}

(DSAEU), Associate Professor, Candidate of Agricultural Sciences, Professor, Department of Soil Sciences and Farming, Ukraine

\begin{abstract}
Improving the technology of reclamation of disturbed lands, leading to the formation of technozems is justified. Parameters of changes in edaphic characteristics of technozem models of different quality in lithogenic composition depending on time as a factor of soil formation in the conditions of the Pokrov experimental station of land reclamation were determined. The long-term (more than 50 years) impact of intensive phytomelioration contributed to an increase in nutrients in technosols, optimization of physical and biological properties was determined.The loose, crumbly rocks of tertiary and quaternary deposits deposited at the dumps form edaphotopes that have no analogues in nature. Disturbed rocks do not retain their former physical, chemical and biochemical properties and are characterized by a large heterogeneity, complex soil and environmental conditions: a low content of nutrients and lack of moisture for vegetation and microorganisms - producers of soil enzymes. Features of growth of enzymatic activity in the formation of "young" soils were revealed. Gradation of the degrees of biogenicity of edaphotopes by enzyme activity has been improved. The content of trace elements in plants grown on rocks was studied.
\end{abstract}

Keywords: rocks, biological reclamation, technozems, trace elements, plants. 


\section{Introduction}

Mining activities can cause drastic disturbances in soil properties, which adversely affect the nutrient cycling and soil environment. The suitability of rocks taken up to the day surface as a result of open mining for biological reclamation is determined by their physical, chemical and biological properties [1]. Destruction and grinding of the soil structure at the initial technological stage is due to the use of a rotary complex [2]. This process leads to an increase in the content of small particles of different quality rocks and black soil. As a result, the water characteristics of the substrates also change. The study of physical properties of reclaimed land depends on the specific indexes of substrates, the method of their formation and biological development. The technology of creating model two and multilayers lyzymeter and field experiments determines the differentiation of the density, porosity, aeration borehole, humidity state along the artificial reclamation profile. In the process of open-pit mining, the hydrological regime of not only waste dumps, but also the environment is violated [3]. The availability of moisture to plants is largely due to its movement in specific ground conditions. Water characteristics depend on the soil texture. Water in the soil is in continuous motion: it accumulates and is consumed, turns from one form to another, and is used by plants. As a result of the functioning of the root systems of plants and various physiological groups of microorganisms, enzymes accumulate, which are accumulated by the organo-mineral part of edaphotops. These functional manifestations are the ecological basis that contributes to the restoration of ecosystems and are an integral part of the ecological rehabilitation of used land [4]. The correlation analysis shows that soil organic carbon contents in aggregate fraction of $0.25-0.5 \mathrm{~mm}$ were correlated with aggregate distribution and enzyme activities [5]. The non - top - soiled areas, even after 6, 7 and 8 years, appeared to have lower enzyme activities than the younger top soiled areas or the undisturbed soil. The effects of top-soiling and reclamation age on dehydrogenase, nitrogenase, phosphatase, arylsulphatase, amylase, cellulase, invertase and urease activities were evaluated on three reclaimed non-top-soiled and five reclaimed topsoiled areas and compared with an undisturbed reference soil [6]. Optimization of the properties of model structures of technosols in the process of long-term biological reclamation and use is slow. After all, 
enzymes significantly affect the biochemical processes, and subsequently the level of culture of the microorganisms. The main objective is to study water-physical, nutrition regimes and oxidizingreducing conditions the phytomeliorated rocks of Nikopol manganese ore mining basin.

\section{Materials and Methods.}

The experiments were conducted at the Pokrov Reclamation Research Station of DSAEU, located at $47^{\circ} 39^{\prime}$ N, $34^{\circ} 08^{\prime}$ E, with an elevation of $60 \mathrm{~m}$. The mining rocks are taken up to the surface during process of manganese ore mining [7]. The stratigraphy of the Nikopol manganese ore basin is shown in table 1 .

Table 1

Rock deposits stratigraphy

\begin{tabular}{|c|c|c|}
\hline Age & Depth, $\mathrm{m}$ & Name of substrate \\
\hline $\mathrm{Q}$ & $0-7$ & Soils, loess-like loam \\
\hline $\mathrm{N}_{1} \mathrm{SQ}$ & $7-12$ & Red-brown loam and clay \\
\hline $\mathrm{N}_{1} \mathrm{Srm}^{2}+1$ & $12-47$ & Grey-green clay \\
\hline $\mathrm{N}_{1} \mathrm{Srm}_{1}$ & $47-63$ & Sand-clay deposits \\
\hline $\mathrm{Pg}_{1} \mathrm{ch}_{1}$ & $63-71$ & Green montmorillonite clay \\
\hline $\mathrm{Pg}_{1} \mathrm{ch}_{1}$ & $>71$ & Manganese ore \\
\hline
\end{tabular}

$Q$ - quaternary; $\mathrm{N}_{2}$ - Pliocene, upper (late) Neogene; $\mathrm{N}_{1}-$ Miocene, lower (early) Neogene; Srm1 - lower Sarmat; $\mathrm{Srm}^{2}$ - middle Sarmat; $\mathrm{Srm}^{3}$ - upper Sarmat; Pg3 Oligocene, upper Palaeogene.

Accepted conventional meanings for the substrata as following: SBS - southern black soil; LLL - loess-like loam; RBL - red-brown loam; RBC - red-brown clay; GGC - green-grey clay; GMC - green montmorillonite clay; AAS - ancient-alluvial sand; DGSC - dark-grey schist clay. The soil mass was taken off, piled up and heaped onto the land after the rock has been replaced (Fig.1). Substrates formed in this way can be attributed to the category of technosol [8]. Technosol are soils dominated or strongly influenced by human-made materials and correspond to soils whose properties and pedogenesis are dominated by technical origin. Their parental material is made of all kind of materials made or exposed by human activity that otherwise would not occur at the Earth's surface. Rock and soil substrata were tested in different artificial profiles to estimate their physical - chemical properties in lyzimeter experiments (Fig 2). 

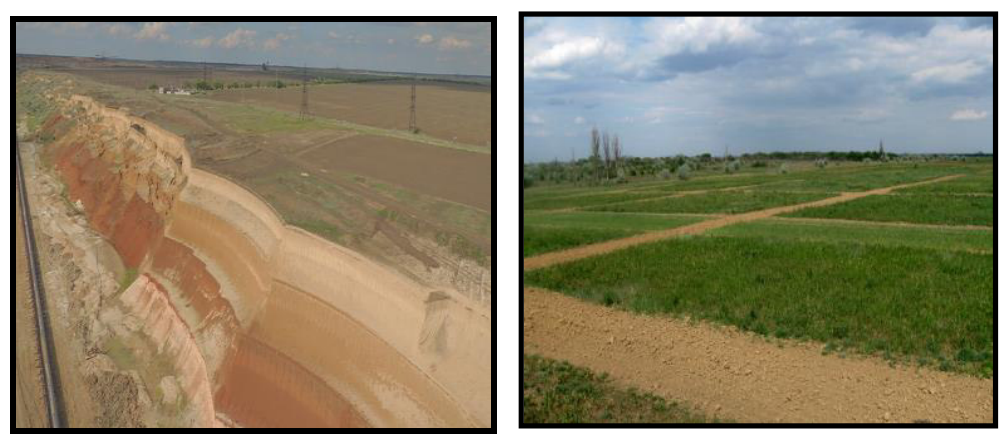

Fig. 1. Quarry board (left) and field experiments (right)
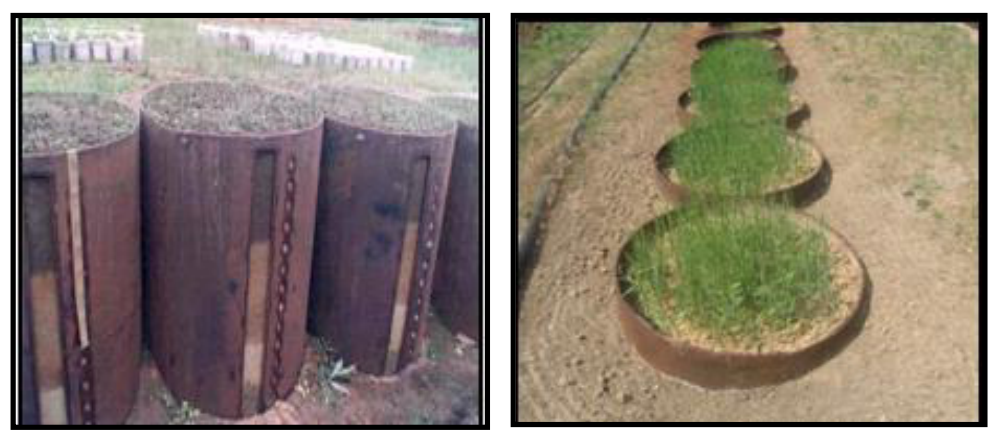

Fig. 2. Model experiments in lyzimeters at Pokrov land reclamation station

Several models of rock substrates were tested: 1) loess-like loam (LLL), taken from the board of the quarry $(0-150 \mathrm{~cm}) ; 2)$ red-brown clay $(\mathrm{RBC})$ taken from the board of the quarry $(0-150 \mathrm{~cm}) ; 3)$ greengrey clay (GGC) taken from the board of the quarry $(0-150 \mathrm{~cm}) ; 4)$ black soil $(0-50 \mathrm{~cm})+$ loess-like loam $(50-150 \mathrm{~cm})$; 5) ) black soil $(0-$ $50 \mathrm{~cm})+$ Sand $(50-70 \mathrm{~cm})+\operatorname{LLL}(120-150 \mathrm{~cm}) 6)$ black soil $(0-$ $50 \mathrm{~cm})+$ loess-like loam $(50-100 \mathrm{~cm})+$ sand $(100-120 \mathrm{~cm})+$ greengrey clay $(120-150 \mathrm{~cm})$

The mechanical, physical, chemical and biological properties of some rock substrata were studied with use of standard methods [9]. The main minerals of rocks silty fraction consist of feldspar, calcite, illite, montmorillonite, chlorite and kaolinite. Previous studies have revealed differences in the content of montmorillonite and illite [10]. 
Their bigger content causes a higher plasticity of grey-green and redbrown clays.

In order to determine mineral elements contents samples weighing $2 \mathrm{~g}$ were combusted in a muffle furnace at $450^{\circ} \mathrm{C}$ by means of drying method and then dissolved in $5 \mathrm{ml} 6 \mathrm{~N}$ spectral purity hydrochloric acid. Determination of trace elements contents in obtained mineralizates were made by means of flame using a spectrophotometer Saturn 3. The obtained data on chemical properties of the plant studied represent the arithmetic means of three replicates of each sampling, their ranges and standard deviations values.

\section{Water-physical properties and nutrition regimes of reclaimed minelands}

The water regime of soils of the dumps is changed under the action of gravity, meteorological conditions, hydrogeological situation and the type of vegetation cover [11]. Heterogeneity of factors determines the spatial differentiation of the hydrological regime of the soil cover. The indicators of maximum hygroscopicity in the upper layers of technozems are higher than in the humus horizon of the black soil after 15 years of formation of technozems (Table 1). Maximum hygroscopicity is constantly increasing due to the long-term reclamation effect of plants on the soil. The texture and compaction of the soil affect the formation of an artificial reclamation profile. The models with red-brown and gray-green clays were distinguished by the highest indicators of the productive moisture reserve. The moisture content and water regime in technosol models changes in comparison with the initial data and depends on meteorological conditions, soil texture and organic matter content. The nutritional regimes of artificial reclamation profiles were determined (Table 2). Resources of humus and macroelements status determine the structures of technozems. The use of potentially fertile rocks and their mixtures as the main substrates is possible for artificial reclamation profiles creating. The estimation of easily accessible (AAB pH 4.8) and hard-to-reach $(1 \mathrm{~N} \mathrm{HCl})$ reserves of phytomeliorated substrates in relation to heavy metals is given in table 3 . 
Table 1

Water-physical properties of edaphic modul structures of the Nikopol manganese deposit (based on 0-100 cm layer)

\begin{tabular}{l|l|l|l|l|l}
\hline $\begin{array}{l}\text { Substr } \\
\text { ata }\end{array}$ & $\begin{array}{l}\text { Maximum } \\
\text { water } \\
\text { absorption, } \\
\%\end{array}$ & $\begin{array}{l}\text { Humidity } \\
\text { persistent } \\
\text { fading, \% }\end{array}$ & $\begin{array}{l}\text { The } \\
\text { smallest } \\
\text { moisture } \\
\text { capacity, \% }\end{array}$ & $\begin{array}{l}\text { Range } \\
\text { active } \\
\text { moisture, \% }\end{array}$ & $\begin{array}{l}\text { Moisture } \\
\text { reserves, } \\
\text { mm } \\
\text { in layer 0 - } \\
100 \mathrm{~cm}\end{array}$ \\
\hline BS & $\begin{array}{c}6.3 \\
(5.5-7.4)\end{array}$ & $\begin{array}{c}8.4 \\
(7.2-9.3)\end{array}$ & $\begin{array}{c}28.6 \\
(27,4-30,6)\end{array}$ & $\begin{array}{c}20.2 \\
(18.6-21.4)\end{array}$ & $\begin{array}{c}337 \\
(295-348)\end{array}$ \\
\hline LLL & $\begin{array}{c}6.8 \\
(5.8-7.3)\end{array}$ & $\begin{array}{c}9.1 \\
(8.6-10.3)\end{array}$ & $\begin{array}{c}25.5 \\
(24.8-30.8)\end{array}$ & $\begin{array}{c}16.4 \\
(15.3-17.3)\end{array}$ & $\begin{array}{c}352 \\
(344-486)\end{array}$ \\
\hline RBC & $\begin{array}{c}11.4 \\
(9.5-12.6)\end{array}$ & $(14.1-16.7)$ & $\begin{array}{c}35.8 \\
(34.6-37.2)\end{array}$ & $\begin{array}{c}20.5 \\
(18.9-22.1)\end{array}$ & $\begin{array}{c}457 \\
(411-524)\end{array}$ \\
\hline GGC & $\begin{array}{c}15.7 \\
(13.8-17.1)\end{array}$ & $\begin{array}{c}21.0 \\
(19.2-23.4)\end{array}$ & $\begin{array}{c}42.1 \\
(40.7-43.6)\end{array}$ & $\begin{array}{c}21.1 \\
(20.2-22.8)\end{array}$ & $\begin{array}{c}552 \\
(543-566)\end{array}$ \\
\hline
\end{tabular}

Table 2

Nutritional regime of some artificial relamation profiles

\begin{tabular}{|c|c|c|c|c|c|c|c|c|}
\hline \multirow{2}{*}{ Depth, cm } & \multicolumn{4}{|c|}{ BS+LLL } & \multicolumn{4}{|c|}{ BS+LLL+Sand+GGC } \\
\hline & $A^{*}$ & $B^{*}$ & $C^{*}$ & $D^{*}$ & $A$ & $B$ & $C$ & $D$ \\
\hline $0-10$ & 2.2 & 0.1 & 1.47 & 34.7 & 2.41 & 0.22 & 1.46 & 35.5 \\
\hline $10-20$ & 2.13 & 0.18 & 1.54 & 33.8 & 2.47 & 0.21 & 1.49 & 34.8 \\
\hline $20-30$ & 2.08 & 0.16 & 1.51 & 29.5 & 2.38 & 0.19 & 1.50 & 32.6 \\
\hline $30-40$ & 2.11 & 0.16 & 1.44 & 25.3 & 2.31 & 0.14 & 1.46 & 31.1 \\
\hline $40-50$ & 1.97 & 0.14 & 1.44 & 24.2 & 2.29 & 0.13 & 1.44 & 27.4 \\
\hline $50-60$ & 0.66 & 0.06 & 1.21 & 13.3 & 1.18 & 0.06 & 1.21 & 17.6 \\
\hline $60-70$ & 0.58 & 0.06 & 1.21 & 12.7 & 1.12 & 0.05 & 1.19 & 16.4 \\
\hline $70-80$ & 0.58 & 0.05 & 1.17 & 12.4 & 1.03 & 0.05 & 1.16 & 15.7 \\
\hline $80-90$ & 0.51 & 0.04 & 1.15 & 12.3 & 0.72 & 0.03 & 1.11 & 14.2 \\
\hline $90-100$ & 0.46 & 0.04 & 1.14 & 12.2 & 0.68 & 0.03 & 0.09 & 13.1 \\
\hline $100-110$ & 0.45 & 0.03 & 1.12 & 12.2 & 0.09 & 0.008 & 0.09 & 4.7 \\
\hline $110-120$ & 0.45 & 0.03 & 1.11 & 11.9 & 0.09 & 0.008 & 0.08 & 4.8 \\
\hline $120-130$ & 0.42 & 0.02 & 1.10 & 11.8 & 0.19 & 0.02 & 0.35 & 57.6 \\
\hline $130-140$ & 0.42 & 0.01 & 1.09 & 11.7 & 0.19 & 0.01 & 0.31 & 57.2 \\
\hline $140-150$ & 0.41 & 0.01 & 1.09 & 11.7 & 0.17 & 0.01 & 0.29 & 56.1 \\
\hline \multicolumn{9}{|c|}{$\begin{array}{l}\text { A - humus, \%; B - total nitrogen, \%; } \mathrm{C} \text { - mobile phosphorus, } \mathrm{mg} / 100 \mathrm{~g} \text {; } \\
\mathrm{D} \text { - exangable potassium, } \mathrm{mg} / 100 \mathrm{~g}\end{array}$} \\
\hline
\end{tabular}


The content of trace elements in black soil and rocks, mg / $\mathrm{kg}$ (numerator-AAB $\mathrm{pH}$ 4.8 , denominator- $1 \mathrm{~N} \mathrm{HCl}$ )

\begin{tabular}{l|l|l|l|l|l|l}
\hline Soil & $\mathrm{Fe}$ & $\mathrm{Mn}$ & $\mathrm{Zn}$ & $\mathrm{Cu}$ & $\mathrm{Ni}$ & $\mathrm{Cr}$ \\
\hline \multirow{3}{*}{ BS } & $5.0 \pm 0.5$ & $140 \pm 3$ & $16.0 \pm 1.3$ & $1.96 \pm 0.4$ & $1.8 \pm 0.3$ & $1.0 \pm 0.04$ \\
\cline { 2 - 7 } & $1747 \pm 7$ & $535 \pm 17$ & $62.0 \pm 8$ & $8.3 \pm 0.4$ & $8.4 \pm 0.4$ & $3.0 \pm 0.2$ \\
\hline \multirow{2}{*}{ LLL } & $5.0 \pm 0.5$ & $70 \pm 3$ & $10.0 \pm 1.1$ & $2.5 \pm 0.04$ & $3.6 \pm 0.6$ & $2.0 \pm 0.1$ \\
\cline { 2 - 7 } & $1283 \pm 7$ & $343 \pm 20$ & $81.0 \pm 8.1$ & $6.6 \pm 0.2$ & $7.9 \pm 0.5$ & $3.1 \pm 0.2$ \\
\hline \multirow{2}{*}{ RBL } & $4.3 \pm 0.2$ & $62 \pm 4$ & $11.3 \pm 2.2$ & $2.8 \pm 0.2$ & $3.8 \pm 0.2$ & $2.2 \pm 0,1$ \\
\cline { 2 - 7 } & $1243 \pm 3$ & $348 \pm 7$ & $28.3 \pm 2,4$ & $6.8 \pm 0,2$ & $8.43 \pm 0.1$ & $3.0 \pm 0.2$ \\
\hline \multirow{2}{*}{ RBC } & $4.0 \pm 0.2$ & $68 \pm 3$ & $9.5 \pm 1.8$ & $2.3 \pm 0.2$ & $3.2 \pm 0.2$ & $1.9 \pm 0.1$ \\
\cline { 2 - 7 } & $1848 \pm 108$ & $467 \pm 7$ & $35.0 \pm 3.6$ & $8.57 \pm 0.3$ & $11.3 \pm 0.3$ & $3.8 \pm 0.1$ \\
\hline \multirow{2}{*}{ GGC } & $4.4 \pm 0.1$ & $51 \pm 4$ & $5.9 \pm 1.7$ & $2.2 \pm 0.3$ & $2.7 \pm 0.15$ & $1.4 \pm 0.21$ \\
\cline { 2 - 7 } & $1082 \pm 43$ & $155 \pm 15$ & $16.3 \pm 3$ & $7.3 \pm 0.7$ & $4.0 \pm 0.32$ & $3.5 \pm 0.3$ \\
\hline \multirow{2}{*}{ DGC } & $11.2 \pm 2$ & $206 \pm 19$ & $8.7 \pm 1.1$ & $2.2 \pm 0.2$ & $5.8 \pm 0.8$ & $1.3 \pm 0.1$ \\
\cline { 2 - 7 } & $2005 \pm 111$ & $2053 \pm 80$ & $35.8 \pm 4.4$ & $8.22 \pm 0.6$ & $9.2 \pm 1$ & $3.0 \pm 0.3$ \\
\hline \multirow{2}{*}{ GLC } & $4.7 \pm 0.5$ & $50 \pm 2$ & $11.7 \pm 0.6$ & $2.1 \pm 0.3$ & $1.5 \pm 0.2$ & $1.3 \pm 0.02$ \\
\cline { 2 - 7 } & $1330 \pm 147$ & $291 \pm 14$ & $37.2 \pm 1.9$ & $7.9 \pm 0.2$ & $3.5 \pm 0.5$ & $3.3 \pm 0.5$ \\
\hline
\end{tabular}

The increased concentration of manganese in dark gray clay limits the prospect of using this substrate during creating of reclaimed land.

Meanwhile, the content of trace elements in the remaining weathered rocks did not exceed the indicators of the black soil. The highest degree of microelements balance was fixed loess like and red-brown loam, red-brown and gray-green clay.

Elongated plant melioration leads to an increase in the share of available reserve of trace elements in these substrates during the process of biological weathering of rocks.

The level of trace elements in weathered rocks did not exceed the indicators of black soil even after 14 years of their phytomelioration.

Trace elements spectrum was studied to assess the species differences in their concentration in the vegetative mass of plants, when growing barley, peas and alfalfa in the pot experiments with black soil and three phytomeliorated rocks.

The results of these studies are shown in figures 3 and 4 . 


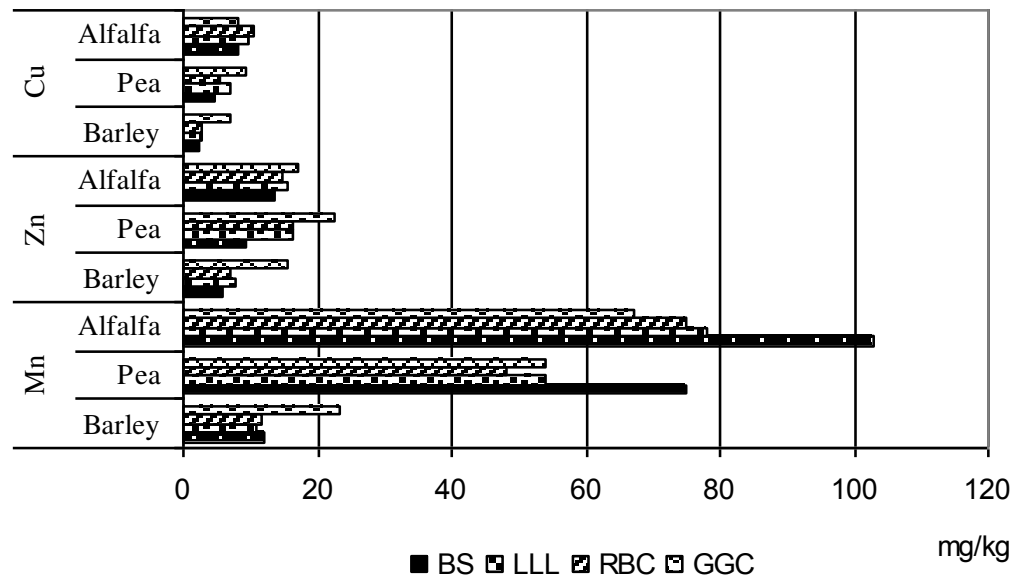

Fig. 3. $\mathrm{Mn}, \mathrm{Zn}, \mathrm{Cu}$ content in aboveground biomass of crops

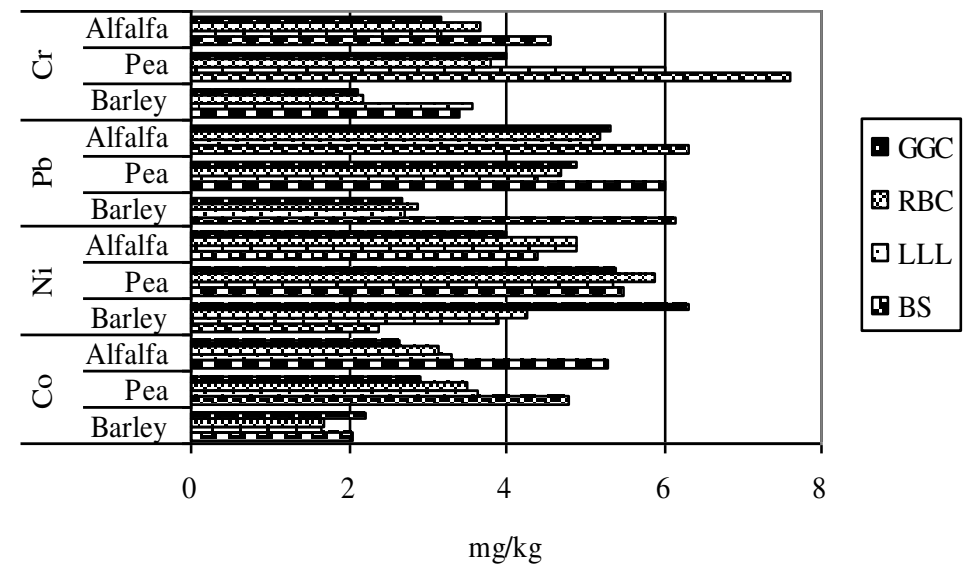

Fig. 4. $\mathrm{Co}, \mathrm{Ni}, \mathrm{Pb}, \mathrm{Cr}$ content in aboveground biomass of crops

It was found that the content of trace elements in the aboveground mass of barley, peas and alfalfa grown on three phytomeliorated rocks (loess-like loam, red-brown and gray-green clay) it is comparable to the data obtained when growing these plants on black soil.

Evaluation of enzymatic activity in phytomeliorated rocks 
Research of enzymatic activity in rocks after their 33-year phytomelioration. The results of research indicate that the change in humus content is slow, while the activity of enzymes increases significantly. For example, the humus content in the loess like loam taken directly from the quarry was $0.5 \%$. However, invertase activity was not observed here. The content of humus in the upper 20-cm layer increases almost 2 times after 33-year phytomelioration of loess like loam (Fig. 5).

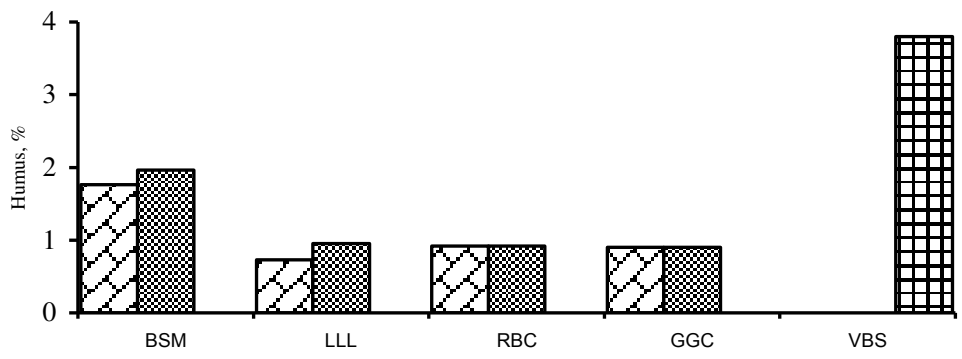

$\square 18$ - year plant melioration $\mathbf{0} 33$ - year plant melioration $\mathbf{0}$ black soil

Fig. 5. A change in the content of humus in edaphotope under phytocenozes in the layer $0-20 \mathrm{~cm}$

The upper 40-centimeter thickness of the studied edaphotopes under vegetation cover reaches an average level of enrichment with the enzyme invertase. The greatest growth (up to 2.5 times) of this parameter is observed in the layer of $0-20 \mathrm{~cm}$ loess-like loam (Fig. 6). Red-brown clay had the poorest level of invertase activity after 18 years of plant melioration process. The increase in the level of invertase activity in the upper $20-\mathrm{cm}$ horizon was 1.6 times in the next 15 years of phytomelioration. The growth of invertase activity in the upper layer of black soil and gray-green clay is less intense. The active interaction of roots and soil microorganisms leads to the fact that the rocks are cultivated faster. The increase in the level of invertase activity occurs more intensively under the influence of vegetation process over the past 15 years in the $20-40 \mathrm{~cm}$ layer compared to the $0-20 \mathrm{~cm}$ layer. 


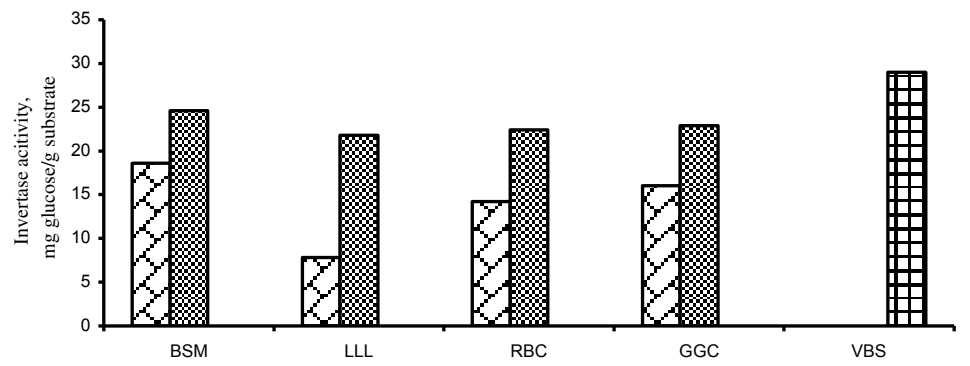

ㄴ 18-year plant melioration $\mathbf{0}$ 33-year plant melioration $\mathbf{Q B}$ Black Soil

Fig. 6. Changes in the level of invertase activity of edaphotopes under the vegetation cover in the $0-20 \mathrm{~cm}$ layer

The parameters of this indicator in the upper layer of black soil and red-brown clay grow by 1.8 times, in gray-green clay - by 2.3 times, and in loess like loam by almost 4 times (Fig. 7).

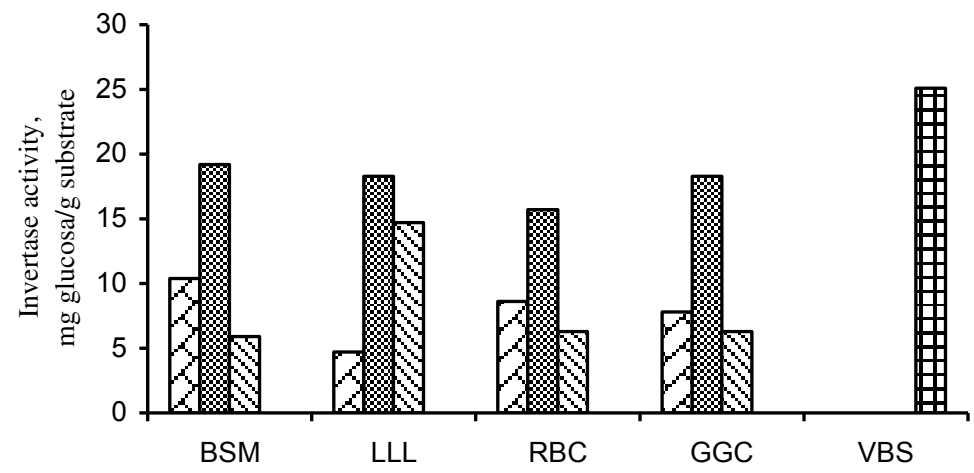

18 - year phytomelioration $(20-40 \mathrm{~cm})$ 圆33 - year phytomelioration $(20-40 \mathrm{~cm})$

Q33-year phytomelioration $(40-60 \mathrm{~cm})$ 田Black Soil

Fig. 7. Changes in the level of invertase activity of edaphotopes under phytocenoses in the $20-60 \mathrm{~cm}$ layer

Intensive hydrolysis of glycosides in a layer of 40-60 cm was recorded only for loess like loam. Invertase activity of loess like loam in the horizon of $40-60 \mathrm{~cm}$ is $14.7 \mathrm{mg}$ of glucose/g of suspension 
after 33 years of this edaphotope under the influence of vegetation process. This exceeds the 18-year level of this indicator for a layer of $20-40 \mathrm{~cm}$ by almost 3 times. Thus, over the past 15 years, the loesslike loam layer has been cultivated most intensively under the influence of phytomelioration. In other words, loess-like loam is the most suitable rock for the formation of zonal soil in natural conditions. Urease catalyzes the hydrolysis of urea to ammonia and plays an important role in optimizing the nitrogen balance in the edaphotopes of man-made landscapes. Urease activity in the $0-20 \mathrm{~cm}$ layer increased little after 18-year rocks phytomelioration (Fig. 8).

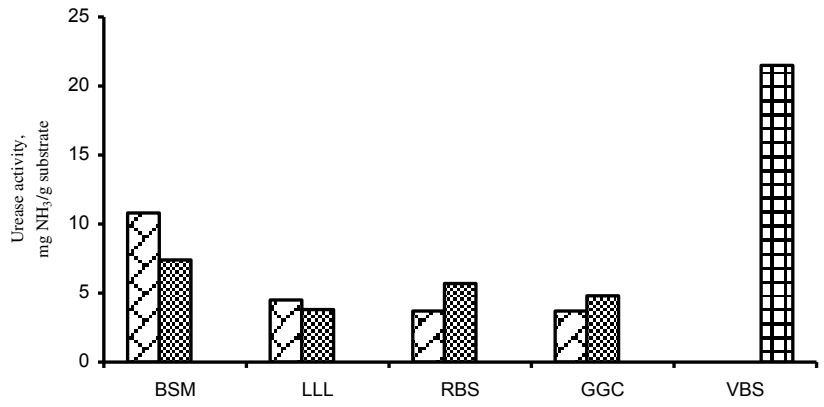

$\square 18$ - year phytomelioration $\mathbf{0} 33$ - year phytomelioration $\mathbf{\boxplus B}$ Black soil

Fig. 8. Changes in the level of urease activity in the $0-20 \mathrm{~cm}$ edaphotops

The change in the level of urease activity in the $0-20 \mathrm{~cm}$ edaphotops due to the action of grass groups of meliorated rocks increased little. The low level of enrichment of rock substrates with urease is explained by the fact that legumes are able to provide themselves with nitrogen. All the studied edaphotopes are characterized by a poor degree of enrichment of urease activity in the upper $20 \mathrm{~cm}$ and after 33 years of phytomelioration. It is known that the phosphatase enzyme is directly related to the processes of biological mobilization of phosphorus from rocks. The upper layers of black soil and loam increased phosphatase enrichment to an average degree in the meliorated rocks after their long-term staying. 
Red-brown and gray-green clays were characterized by a low degree of phosphatase enrichment. The indicators of these two edaphotopes are close to the indicators indicating the average degree of enrichment of rocks with phosphatase.

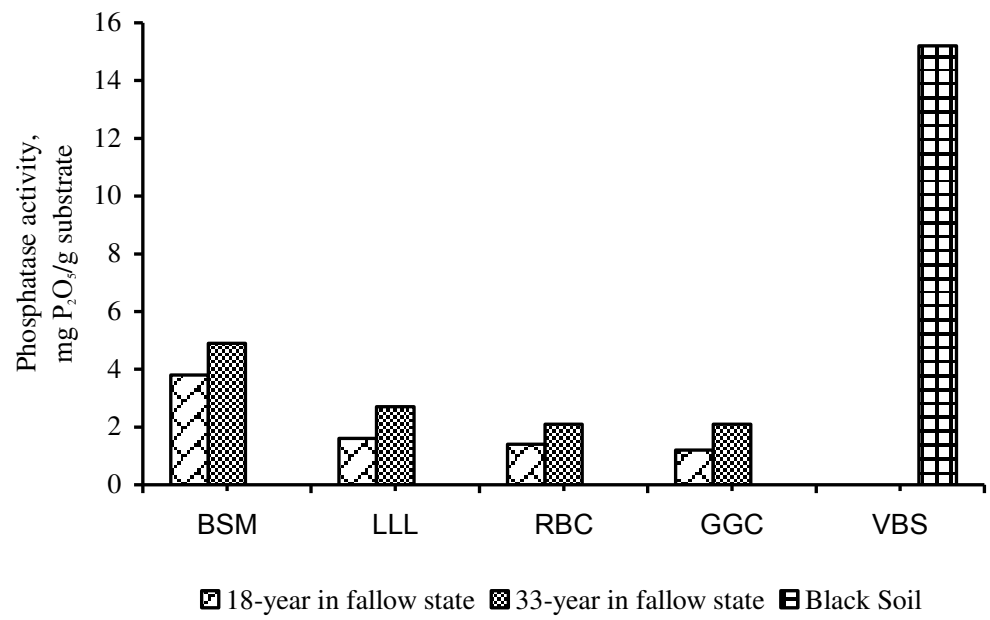

Fig. 9. Changes in the level of phosphatase activity of edaphotopes in the layer $0-20 \mathrm{~cm}$

The growth of phosphatase activity in the upper layer of 0-20 cm occurs under the impact of vegetation growth (Fig.10).

Indicators of activity of this enzyme under phytocenoses are higher in comparison with areas without vegetation cover.

The process of phosphatase accumulation is quite intense in the 0 $20 \mathrm{~cm}$ layer.

The level of phosphatase activity after a 33-year stay of edaphotopes on the day surface in the 40-60 cm layer is almost equal to the 18-year indicators of this parameter for the 20-40 cm layer (Fig. 11 and 12). 


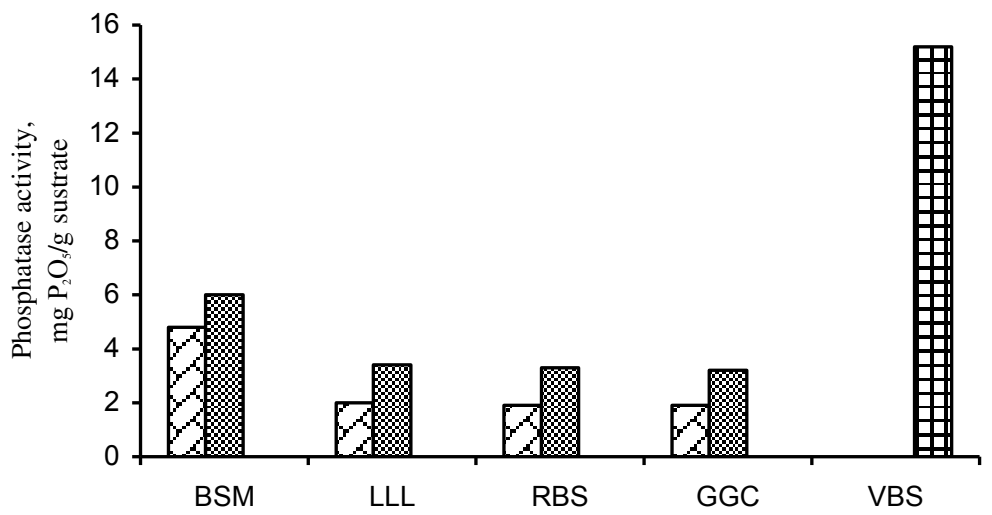

$\square$ 18-year phytomelioration $\mathbf{0} 33$ - year phytomelioration $\boldsymbol{\Xi}$ Black Soil

Fig. 10. Changes in the level of phosphatase activity of edaphotopes under phytocenoses in the 0-20 cm layer

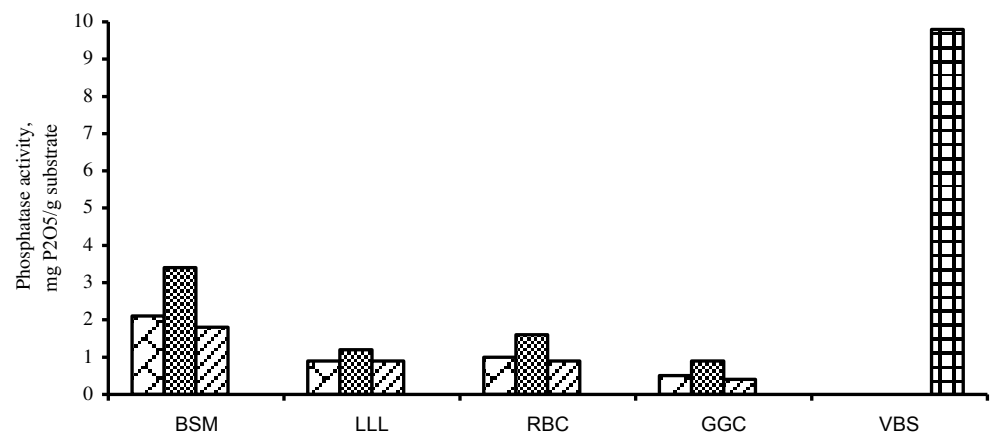

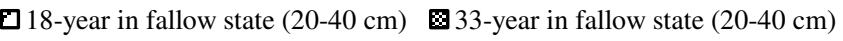
$\square 33$ - year in fallow state $(40-60 \mathrm{~cm})$ 田Black Soil

Fig. 11. Changes in the level of phosphatase activity in the edaphotop layer $20-60 \mathrm{~cm}$ (without vegetation) 


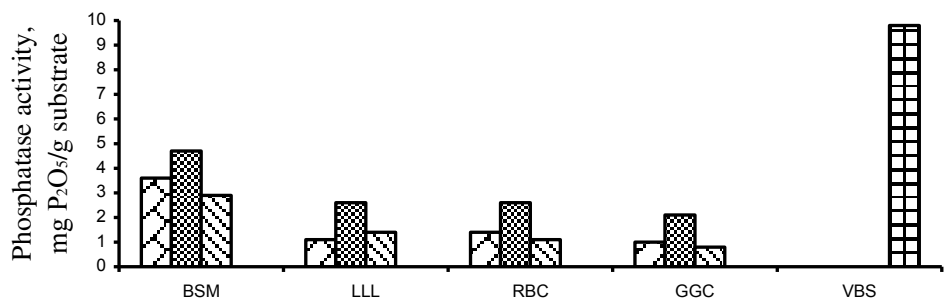

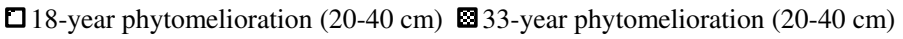
Q33-year phytomelioration $(40-60 \mathrm{~cm})$ 田Black Soil

Fig. 12. Changes in the level of phosphatase activity of edaphotopes under phytocenoses in the $20-60 \mathrm{~cm}$ layer

It is known that the processes of soil formation in phytomeliorated rocks occur with the participation of dehydrogenase. The effect of grass vegetation is outstanding for the formation of dehydrogenase potential. The positive effect of biocenoses is shown in the upper layer of black soil. Meantime the level of dehydrogenase activity under phytocenoses exceeds the activity of this enzyme in samples from the virgin field of black soil (Fig. 13 and 14).

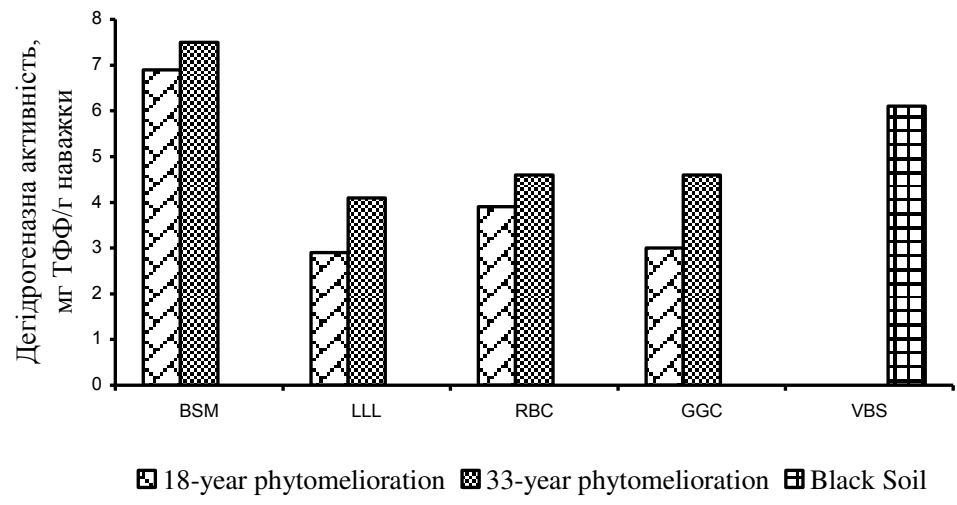

Fig. 13. Changes in the level of dehydrogenase activity in the $0-20 \mathrm{~cm}$ layer under the influence of grass groups 


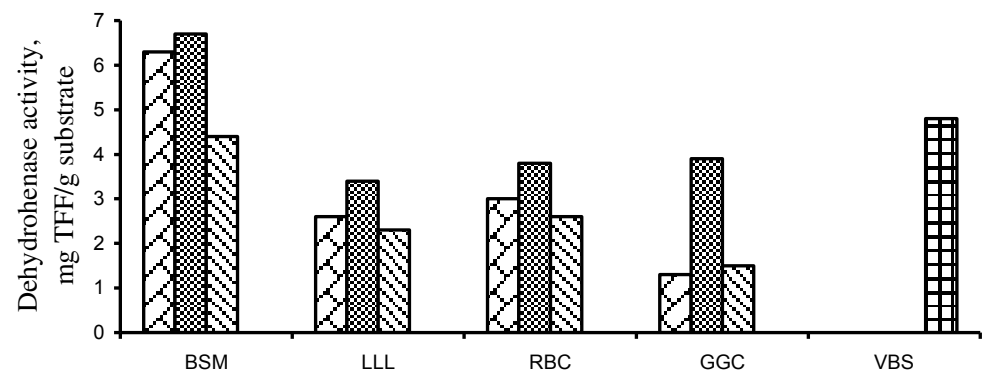

Q18-year phytomelioration $(20-40 \mathrm{~cm})$ 圆33-year phytomelioration $(20-40 \mathrm{~cm})$

Q33-year phytomelioration $(40-60 \mathrm{~cm})$ 田Black Soil

Fig. 14. Changes in the level of dehydrogenase activity in the $20-60 \mathrm{~cm}$ layer due to the action of phytocenoses

The greatest accumulation of the enzyme dehydrogenase occurred over the past 15 years in a layer of gray-green clay due to the phytomeliorative action of herbal groups. The greatest mass of roots and microorganisms accumulated in the gray-green clay stratum. So, the 33-year stay of tertiary clay deposits on the daytime surface was accompanied by an intensive accumulation of dehydrogenase. Usually, catalase activity is evaluated as an indicator of the functional activity of the soil microflora (Fig. 15).

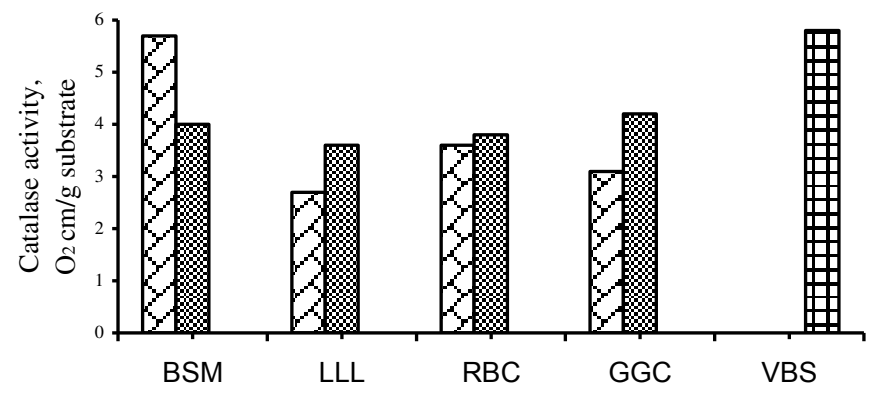

18- year in fallow state $\mathbf{0} 33$ - year in fallow state $\mathbf{Q}$ Black Soil

Fig. 15. Changes in the level of catalase activity in the $0-20 \mathrm{~cm}$ layer of food plants that are in the vapor (without vegetation) state 
Catalase activity in the $0-20 \mathrm{~cm}$ layer reached an average degree of enrichment after 18-year stay on the daytime surface. A significant increase in the activity of catalase in the layer $0-20 \mathrm{~cm}$ edafotop - up to $70 \%$ relative to the control was recorded after 33 years weathering. The level of catalase activity in the edaphotop stratum after 33-year staying under phytocenoses did not exceed the level of activity of this enzyme in zonal black soil and amounted to $88 \%$ relative to the control (Fig. 16).

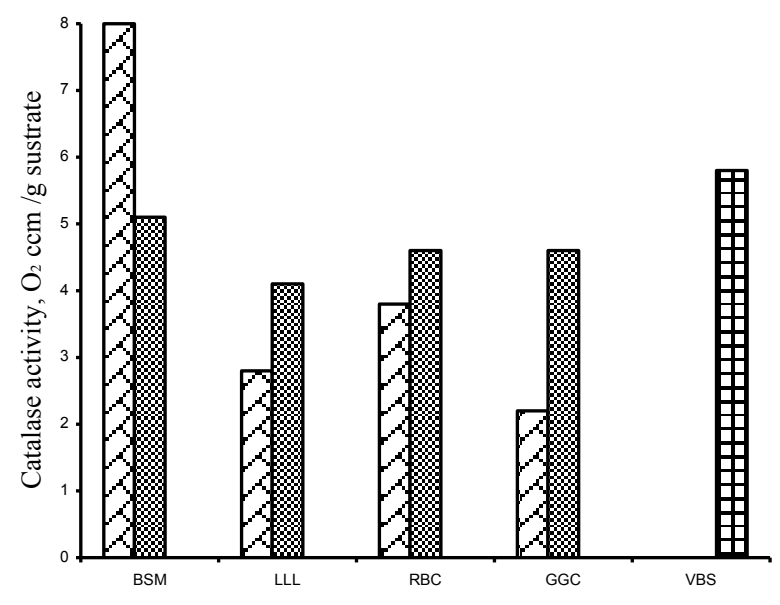

18-year phytomelioration 33 -year phytomelioration mBlack Soil

Fig. 16. Changes in the level of catalase activity in the $0-20 \mathrm{~cm}$ layer in edaphotopes due to the action of herb groups

Consequently, the most intense increase in the activity of redox enzymes occurs in the layer of gray-green clay. Thus, the long-term stay of technogenic landscapes on the day surface (as fallow state, or in the state of arable land) contributes to a significant increase in their enzyme potential. At the same time, there is a more intensive accumulation of activity of hydrolytic enzymes in comparison with redox enzymes. In other words, hydrolysis reactions of complex organic compounds predominate in long term phytomeliorated rocks, and they enrichment of edaphotopes with nutrients available to plants and microorganisms. The process of synthesis of humic substances is 
less intensive. A long stay of rocks on the surface of the day without vegetation contributes to the fact that the level of enzymatic activity they are slowly approaching zonal soils. However, these edaphotopes are characterized as "weakly biogenic". At the same time, it is interesting that in the top layer of the black soil and in the gray-green clay. The recovery of the biochemical potential is faster. That is why, according to the level of activity of enzymes, gray-green clay can be attributed to the mid-biogenic edaphotopes. Phytocenoses contribute to a significant increase in the accumulation of enzyme activity in rocks. Therefore, even in the layer of $20-40 \mathrm{~cm}$, almost all the studied edafotopi, except for red-brown clay, are characterized as biogenic. Thus, the study of the formation of the enzyme potential in the top and subtop stratums of edafotops indicates their gradual approach to the level of zonal black soil due to the process of phytomelioration. On this basis, the following can be argued: a) positive ecological rehabilitation of disturbed lands by open mining; b) restoration of the biochemical potential contributes to increasing the environmental stability of the created phytocenoses, which can withstand harsh steppe conditions and disturbed ecological balance in the region. These functional manifestations are the ecological basis that contributes to both the conservation of ecosystems and their restoration. The study of the growth of enzyme activity in the technozems allows us to know the initial stages of soil formation, the speed and direction of soil-forming processes and ways to accelerate them, the laws of soil formation on a zonal scale.

Numerous studies have shown that enzymes are resistant even to environmental conditions that are unfavorable for the life of microorganisms and the development of plant root systems. The changes to the soil organic carbon, activities of soil enzymes and glomalinrelated soil protein were measured and the effects of arbuscular mycorrhizal fungi (AMF) on activities of soil enzymes and carbon sequestration capacity in reclaimed mine soil were analyzed [12].

It was established that enzyme activity differed in different seasons [13]. All samples indicated different enzyme activity in different seasons.

High enzyme activity was caused by high humidity [14]. Effect of seasonality on biological activity of litter (loss of biomass, enzyme activity, decomposition rate and $\mathrm{C}: \mathrm{N}$ ratio) in litter layer was ap- 
proved as well [15]. So, at the first stages of the formation of technogenic ecosystems, the leading role is played by enzyme activities, which are the starting biotic components.

After inoculation of edaphotop spores of microorganisms brought from nearby natural ecosystems, conditions are gradually created favorable for the functioning of newly formed biocenoses.

Over time, the level of enzyme activity stabilizes, becomes independent of seasonal fluctuations in the number of microorganisms and is a pool that reflects the quality indicators of edaphotops.

Thus, the enzyme pool edaphotops takes part in all stages of transformation of organic compounds.

It is an important regulator of the biochemical homeostasis of waste lands and performs biogeocenotic functions, ensuring the continuity of metabolic processes even in extreme conditions typical of man-made ecosystems.

\section{Environment management of reclaimed minelands}

Improving the management of the reclamation works is proposed to increase the fertility of man-made lands.

This mode means studying the sequence of removal of black soil mass on virgin lands and applying it to the surface of heaps.

Edaphic characteristics of technosol act as indicators of reclaimed lands. Such parameters of edaphic structures of technosol are able to provide stable and high crop yields.

The presence of shrinkage deformations requires additional measures to optimize the terrain.

The costs at the biological stage of reclamation will be determined by a set of technical and phytomeliorative measures that will improve the structural and aggregate state, water-air and nutrient regimes, as well as the biological activity of the restored lands.

It was established that the quality management of technozems provides for the implementation of phytomeliorative measures that will restore their maximum fertility to the level of zonal soils (Table $4)$. 
Table 4

System management of individual properties of technozems

\begin{tabular}{|c|c|c|c|}
\hline Factors & $\begin{array}{l}\text { Parameters } \\
\text { level }\end{array}$ & $\begin{array}{c}\text { Restoration } \\
\text { measures }\end{array}$ & Limiting factor \\
\hline \multirow{6}{*}{ Total } & \multirow{3}{*}{$\begin{array}{l}\text { Low content } \\
\text { humus and } \\
\text { nitrogen }\end{array}$} & \multirow{3}{*}{$\begin{array}{l}\text { Ability to } \\
\text { change multiple } \\
\text { measures }\end{array}$} & Humus accumulation \\
\hline & & & Desalinization \\
\hline & & & $\begin{array}{l}\text { The increase of biological } \\
\text { activity }\end{array}$ \\
\hline & \multirow{3}{*}{$\begin{array}{l}\text { Insufficient } \\
\text { availability of } \\
\text { available } \\
\text { phosphorus }\end{array}$} & \multirow{3}{*}{$\begin{array}{l}\text { Ability to } \\
\text { change one-time } \\
\text { events for a } \\
\text { short period of } \\
\text { time }\end{array}$} & $\begin{array}{l}\text { Providing nutritional } \\
\text { elements }\end{array}$ \\
\hline & & & $\begin{array}{l}\text { Moisture accumulation and } \\
\text { water conservation }\end{array}$ \\
\hline & & & Optimization of air mode \\
\hline \multirow[t]{3}{*}{ Specific } & $\begin{array}{l}\text { Low } \\
\text { aggregation } \\
\text { and formation } \\
\text { of soil crust } \\
\text { on the surface } \\
\text { of } \\
\text { technozems }\end{array}$ & \multirow[t]{2}{*}{$\begin{array}{l}\text { Ability to } \\
\text { change it for a } \\
\text { long time }\end{array}$} & $\begin{array}{l}\text { Increasing the water } \\
\text { resistance of structural units }\end{array}$ \\
\hline & $\begin{array}{l}\text { High level of } \\
\text { toxic salts and } \\
\text { heavy metals }\end{array}$ & & $\begin{array}{l}\text { Desalination } \\
\text { phytoremediation }\end{array}$ \\
\hline & $\begin{array}{l}\text { Heavy soil } \\
\text { texture }\end{array}$ & \multicolumn{2}{|l|}{ Cannot be changed } \\
\hline
\end{tabular}

Creating a common information base for managing edaphic parameters of various technozem structures is the main prerequisite for monitoring the state of nutrient regimes of "young" soils (Fig. 15).

The costs at the biological stage of reclamation are determined by a set of agrotechnical and phytomeliorative measures that will improve the structural and aggregate state, water-air and nutrient regimes, as well as the biological activity of the restored land.

Creating a common information base for managing edaphic parameters of various technozem structures is the main prerequisite for monitoring the state of nutrient regimes of "young" soils (Fig. 15). 


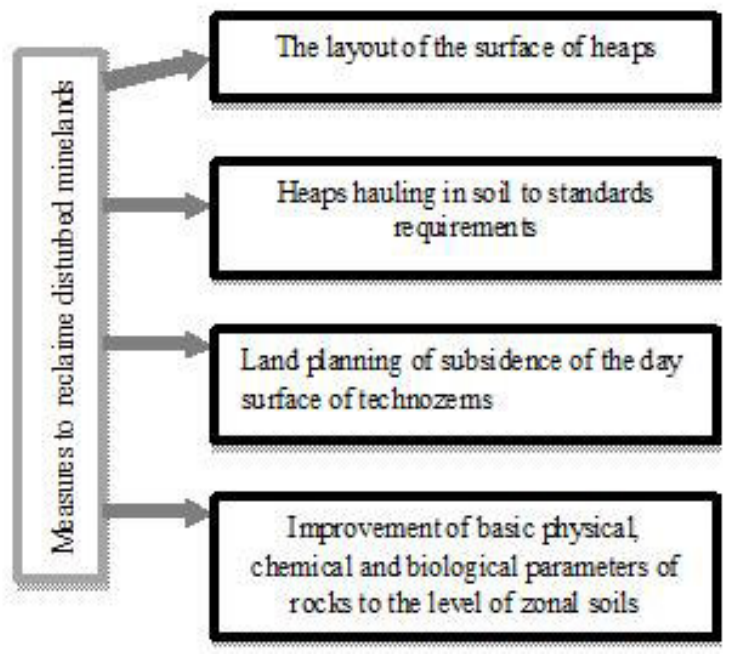

Fig. 17. List of the main types of work aimed at restoring reclaimed dumps

Improving the management of the regime of reclamation works is proposed to increase the fertility of man-made soils.

\section{Conclusions.}

1. The use of efficient technologies reclamation aimed at forming technozems as a bulk layer of fertile soil, and without coverage was estimated. An edaphic parameters of technozems different designs were estimated to develop reasonable and advanced mining technology and biological stages of biological reclamation.

The parameters change edaphic characteristics for various technozems models were analyzed for a long - term phytomelioration and forthcoming using of reclaimed land patterns depending on the time factor as soil formation the "zero moment". The research results complement information database edaphic indicators and their dynamic changes in the different quality models technozems, enabling more effective management of technological processes during the stages of mine technical and biological reclamation. 
2. Change of a level of enzymes activity in meter thickness of artificial land reclamation profiles for certain historical time is demonstrated. The features of accumulation of enzymatic activity at formation of young soils in conditions of technogenic landscapes are revealed. The orientation of biochemical processes in thickness of artificial edaphotopes descends the same as in zonal chernozem: reactions of hydrolysis of complex organic compounds dominate, and process of synthesis of humus substances is carried out slowly. For 33 years of stay on the daily surface of phosphatase, the activity of artificial edaphotopes in terms of the degree of enrichment was the highest in comparison with the activity of other hydrolytic enzymes studied. The most intensive growth of invertase activity occurred in these rocks over the past 15 years. Invertase activity can serve as an indicator of the cultivation of man-made landscapes.

\section{References}

1. Legwaila I. A., Lange E., Cripps J. Quarry reclamation in England: a review of techniques. JASMR, 4(2), 55-79, (2015). doi: 10.21000/jasmr15020055

2. Vondráčková, T., Voštová, V. \& Kraus, M. Mechanization for Optimal Landscape Reclamation. IOP Conference Series: Earth and Environmental Science, 95, (2017). doi: 10.1088/1755-1315/95/2/022042

3. Kuter N. Reclamation of degraded landscapes due to opencast mining. In: Advances in Landscape Archtecture, 33, 823-858, (2013). doi: $10.5772 / 55796$

4. Sheoran V., Sheoran A. S., Poonia P. Soil reclamation of abandoned mine land by revegetation: a review. International Journal of Soil, Sediment and Water, 3(2), 13, (2010).

5. Yin N., Zhang Z., Wang L, Qian K. Variations in organic carbon, aggregation, and enzyme activities of gangue-fly ash-reconstructed soils with sludge and arbuscular mycorrhizal fungi during 6-year reclamation. Environ Sci Pollut Res Int., 23(17), 17840-17849, 2016. doi: 10.1007/s11356-016-6941-5.

6. Fresquez P.R., Aldon E.F., Lindemann W.C. Enzyme activities in reclaimed coal mine spoils and soils. Landscape and Urban Planning, Vol.14, 359-367, (1987). https://doi.org/10.1016/0169-2046(87)90049-1 
7. Tarika O., Zabaluev V. Mine land reclamation strategies in the Nikopol manganese ore basin (Central Steppe of Ukraine: Using replaced mining overburden in agriculture, Prec. of the $16^{\text {th }}$ Ann. Conf. of the Society for Ecological Restoration, Victoria, BC, Canada, 24-26, (2004).

8. Kharytonov M, Pidlisnyuk V, Stefanovska T, Babenko M, Martynova N, Rula I. The estimation of Miscanthus $\times$ giganteus adaptive potential for cultivation on the mining and post - mining lands in Ukraine. Environ Sci Pollut Res Int. Vol. 26(3), 2974-2986, (2019). doi:10.1007/s11356-018-3741-0.

9. Kharytonov M., Babenko M., Mytsyk O., Gavryushenko O., Martynova N. Psysical-chemical and biological testing of phytomeliorated rocks of the Pokrov land reclamation Station. Agrology, l(3), 300-305, (2018). https://doi.org/10.32819/2617-6106.2018.13010

10. Kharytonov M., Resio Espejo J.M. Land reclamation in the manganese ore mining basin in Ukraine.VIII Reunion del Cuaterno Iberico. Sevilla-La Rincioniada, 2013.- Capitulo. 3, 150-152.

11. Kharytonov M.M. Yevgrashkina G.P. The Rocks Mass Properties and Moisture Transfer Process Assessment in the Reclaimed Lands//Sustainable exploitation of natural resources, Proceedings of the Third International Seminar. EcominingEurope in 21- th Centure, Milos Island, Greece, 135-144, (2009).

12. Kuimei Q., Wang L., Ningning Yin N. Effects of AMF on soil enzyme activity and carbon sequestration capacity in reclaimed mine soil. International Journal of Mining Science and Technology.22(4), 553-557, (2012). doi:10.1016/j.ijmst.2012.01.019

13 .Šnajdr J., Valášková V., Merhautová V., Herinková J., Cajthaml T., Baldrian P. Spatial variability of enzyme activities and microbial biomass in the upper layers of Quercus petraea forest soil. Soil Biology and Biochemistry 40, 2068 2075. (2008).

14. Wittmann C., Kahkonen M. A., Ilvesniemi H., Kurola J., Salkinoja - Salonen M. S. Areal activities and stratification of hydrolytic enzymes involved in the biochemical cycles of carbon, nitrogen, sulphur and phosphorus in podsolized boreal forest soils. Soil Biology and Biochemistry 36, 425-433, (2004).

15. Fioretto A., Papa S., Curcio E., Sorrentino G., Fuggi A. Enzyme dynamics on decomposing leaf litter of Cistus incanus and Myrtus communis in a Mediterranean ecosystem. Soil Biology and Biochemistry . 32, 1847-1855, (2000). 